\title{
A gyermekkortörténeti ikonográfia kutatási irányai és lehetőségei
}

\author{
ENDRŐDY-NAgY OrSOLYA \\ Eötvös Loránd Tudományegyetem, Tanító- és Óvóképző Kar
}

\begin{abstract}
A tanulmány felvázolja az ikonográfiai kutatás lehetöségeit, amelyeket a neveléstörténet, illetve szükebb értelemben, a gyermekkortörténet területén képzel el. A 2008 óta hazánkban megjelent tanulmányok, kötetek historiográfiai áttekintésén túl módszertani példán keresztül kísérletet tesz konkrét képek lehetséges elemzésére. Mindezek mellett igyekszik áttekinteni a képolvasás lehetséges metódusát és javaslatot tesz kutatási irányokra, valamint azt taglalja, milyen lehetöségeket ad, ha az ikonográfiai kutatást a szövegek elemzésével együtt használja a jövőben a neveléstörténészek közössége.
\end{abstract}

Kulcsszavak: ikonográfia, gyermekkortörténet, képelemzési módszerek, képolvasás, hermeneutika

Merlin Donald az emberi gondolkodásról írott művében kifejti, hogy az emberi kulturális termékek a szóbeliségen alapuló kultúrákban olyan formákban tárolódtak, mint a vallások, rituálék, szájhagyomány útján átadott irodalmi alkotások, fafaragványok vagy énekek. Ide tartoznak mindazon kulturális eszközök, melyek a tartós külsővé tett emlékezetet szabályokkal és elérési utakkal támogatják (Donald, 2001. 273. o.). Fontos szerepe volt a jeleknek, a vizuális emlékezetnek, képi kifejezésmódnak. Kress és Leuween (2010) vizuális kutatásaik során kimutatták, hogy az 1600-as évek előtt a vizuális világ volt domináns. Jeleket hordoztak a ruhák, ékszerek, díszítés, illetve az embereket körülvevő világ (Huizinga, 1979. 268-270. o.). Emlékeztetnünk kell magunkat arra, hogy az írásbeliség a hatékony írásrendszerek kialakulása után is jóval még mindig a mitikus gondolkodás és a narratív készségek, valamint a különféle performatív tartalmak alárendeltje maradt, és a külső tároló rendszerek építésében elsajátított készségek az uralkodó osztály privilégiumának számítottak (Donald, 2001. 300. o.). Mivel az alfabetizmus a nyomtatás elterjedése előtt elenyésző, a képeknek és a metakommunikációnak is kiemelt szerep jutott. A céhek egyes tagjai mühelyük ajtaja fölé helyezett cégérrel jelezték összetartozásuk. Összességében elmondható, hogy számos jel vette körül a középkori embert, melyeket tudott értelmezni, azaz megtanulta 'olvasni'.
A színek viselésének elemzését például Huizinga a ruházat vizsgálatával teszi meg. Egy párizsi szabó pénztárkönyveinek vizsgálatával rámutat, hogy az ünnepi ruhák esetén a vörös uralkodik, ezt a fehér követi, hétköznapi viseletnél pedig a szürke, fekete és lila gyakori. A kék és zöld erős szimbolikája miatt valamivel ritkább, hisz ezek a szerelem színei. Csupán a barna és sárga nem jellemző a korszak viseletére (Huizinga, 1979). Feltételezem, hogy a középkori emberek értették a metakommunikáció tárgykörébe tartozó jeleket, jelzéseket a középkori ember értette, ismerte a színek jelentését, a szimbólumok jelentését, a festményeket ugyanúgy „olvasta”, ahogy mi értjük manapság a képek, filmek vagy televízióműsorok információit. A középkori Európában élők mindennapjait például átszőtte a keresztény szimbólumrendszer, ahogy a reneszánsz legjelesebb kutatói, Burckhardt és Huizinga jelzik - tisztában voltak a szentek legendáival (Burckhardt, 1978; Huizinga, 1979), épp anynyira, mint amennyire mi a színészek, vagy más meghatározó közéleti személyek életét ismerjük. Végsősoron így kimondható, hogy egy nyelvet beszélt a festő és a néző, azaz alkotó és befogadó ${ }^{\text {. }}$

Ha képesek vagyunk a képek olvasására, miért tartunk mégis a képek értelmezésétől? Többen keressük erre a kérdésre a választ, melyet leginkább akkor tudunk megválaszolni, ha megértjük és elfogadjuk, hogy valóban tartunk a képolvasás mechanizmusától és ezt tesszük 
A gyermekkortörténeti ikonográfia kutatási irányai és lehetőségei

azért, mert sokszor többféle olvasat bizonytalanít el minket. Ugyanakkor Schapiro (1983) szerint a képek sokkal konkrétabbak és komplexebbek a szavaknál, történeteknél. Ha lenne valamilyen módszerünk az olvasás mikéntjére vonatkozóan, akkor biztosabban mernénk a képolvasás felé elmozdulni, a vizuális dokumentumokat az írottakkal egyenértékűnek tekinteni a történeti kutatások során.

A következőkben áttekintem a képolvasás mikéntjére vonatkozó hazai és nemzetközi irodalmakat, majd nemzetközi kitekintéssel a történeti, gyermekkortörténeti ikonográfia feladatait, lehetőségeit tárgyalom.

\section{Mit jelent a képolvasás?}

A képeknek képességük, lehetőségük van arra, hogy olyan információkhoz juttassanak hozzá minket, melyek más úton nem kódolhatóak, vallja Nyíri Kristóf (2009). Ahhoz, hogy ezekhez a kódólt információkhoz hozzájussunk hermeneutikai módszerekre van szükségünk. A képelemzési módszerek segítenek a kutatóknak, hogy megértsék és a képekben kódolt információkat és a szociális kontextust (Kress-Leuween, 2006). Hogyan olvassuk a képeket? Mitől függ a képolvasás mikéntje? Véleményem szerint az olvasást befolyásolja az a tapasztalat, mellyel rendelkezünk a világról, hiszen minden látott kép egy belső képen alapul, a belső képek pedig olyan küldő képeken, melyeket korábban láttunk, észleltünk.

Mindezen túl az olvasás befolyásolhatja a társadalmi kontextusunk, nemünk, világnézeti, vallási hovatartozásunk, az adott időszak és térség, környezet, melybe beleszületünk. Mindezek miatt egy adott képnek számos olvasata lehetséges. Fontos lenne olyan vizuális elemzési módszereket megalkotni, melyek a fenti tényezők hatásait figyelembe veszik (1. 1. ábra).

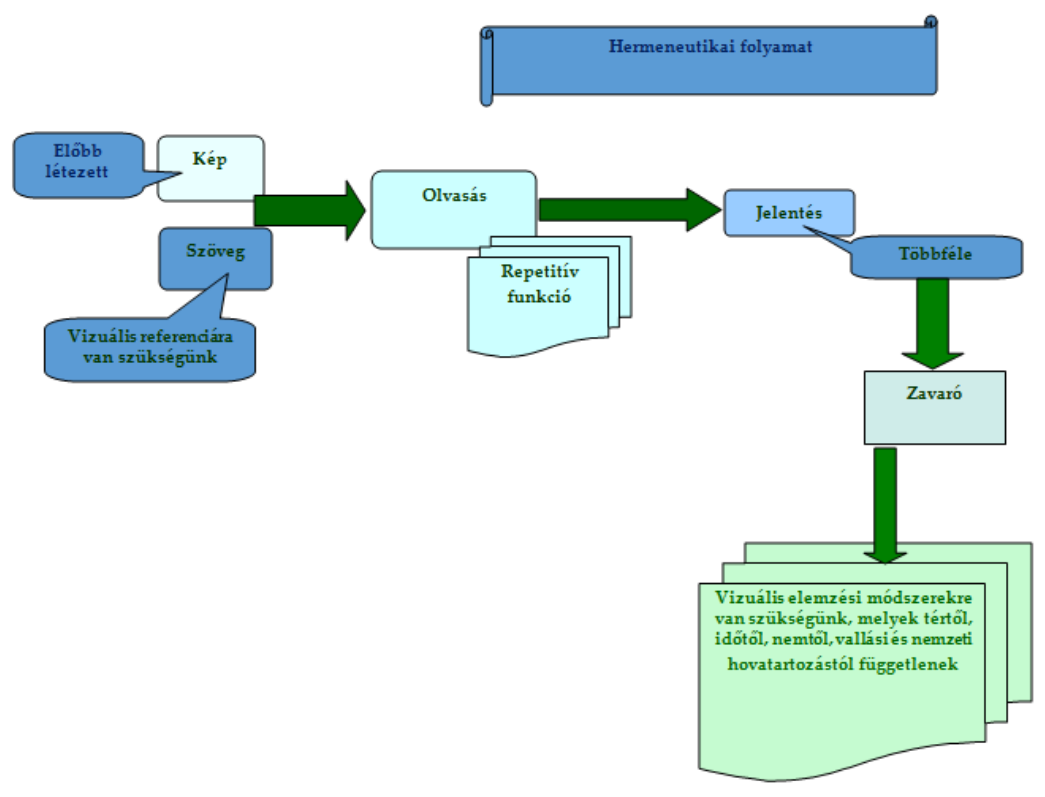

1. ábra: A képolvasás lehetséges folyamata

Az 1. ábra igyekszik tömören bemutatni, hogy olvassuk, dekódoljuk a képeket, illetve hogy milyen módszertanra van annak érdekében szükségünk, hogy ne tartsunk annyira a képek és szövegek kutatásban való egyenértékű alkalmazásától. Asmann A kulturális emlékezet című kötetében (2013) kifejti, hogy a kép előbb volt, mint a szöveg, azaz a vizualitást az emberi agy korábban volt képes képi külső tárolóban megjeleníteni és kódolni, mint írott formában. Példaként az ékírást hozza fel, mely a képek egyszerüsítésével alakult ki. Kötetében az ékírás, és így a kép alapú írások esetén felhívja a figyelmet a repetitív, ritualisztikus funkcióra. A Gilgamesben például a parallelizmusok, ismétlések problémákat jelenthetnek az értelmezés, befogadás szempontjából (Asmann, 2013. 253-257. o.). 
Ugyanígy példaként említhetjük a sokszorosító grafikai eljárásokat, melyeket például az ősnyomtatványok vizuális gazdagítására használtak és adott jelenet többször is előfordulhatott egy-egy kötetben, más-más történet illusztrálására. Erre láthatunk például Schedel Weltcronicjában is (Endrödy-Nagy, 2015b) ${ }^{1}$. Érdekes felfedezni olyan ma is létező írásrendszereket, mint például a japán, ahol a mai napig az írott szöveg olvasása is elbizonytalanító lehet, hiszen a következő szótagtól, kandzsitól függ az adott jelentése. Kulcsár-Szabó Zoltán A kép és a jelentés a retorikai olvasásban címü fejezetben felhívja a figyelmet arra, hogy a képolvasás korántsem megnyugtató folyamat, kép és alakzat, azaz, kép és korábban tapasztalt belső kép, valamint az érzékelés és a megélt külső kép sokrétű lehet (Kulcsár-Szabó, 2005). KulcsárSzabó utal Gadamerre, aki pedig az Igazság és módszerben fejti ki, hogy az egyértelmü jelentésre való visszautalást az alkotó és befogadó megértésfolyamata gátolja. (Gadamer, 1997; Kulcsár-Szabó, 2005). Bal kifejti, hogy a kép és értelmezése egy kölcsönhatás eredménye, fontos minden egyes kép esetén az értelmezés diskurzusa és a sokrétűség minden esetben az értelmező beágyazottságától, saját kontextusától is függ, végsősoron kultúrafüggő. Az elemző nézetein, normáin, ideológiáin, hátterén keresztül szűrődnek (Bal, 1998. 159. o.) Mindezek miatt egy képelemzési módszer esetén fontos lenne figyelembe venni az alkotó és befogadó kontextusát is. Az interdiszciplináris kutatás lehetőséget ad arra, hogy egy adott képet mélyebben megértsünk, elemezzünk (Bal, 1998. 158. o.) - erre tesz kísérletet a már nevéből is következően több tudományterületen átívelő gyermekkortörténeti ikonográfia.

\footnotetext{
${ }^{1}$ Schedel Liber Cronicam, vagy Weltcronic, azaz Krónikák könyve, 645 dúcot tartalmazó mü, 1808 metszet jelenik meg benne, ami azt jelenti, hogy van olyan kép, amit többször is, különféle szituációk illusztrálására alkalmaznak (Endrődy-Nagy, 2015a; 2015b).
}

\section{A történeti ikonográfia mint a gyermekkortörténeti ikonográfia 'szülője'}

Az ikonográfia szó etimológiai eredetét keresve az ikon (eikon) és -gráfia szavak öszszetételéhez jutunk, melyből az ikon a kép a gráfia a leírás szavakat takarja². Eredetileg a művészettörténet segédtudománya.

Basics Beatrix már első történeti ikonográfiával foglalkozó tanulmányában jelezte, hogy a történeti ikonográfiára mint résztudományra tekint a művészettörténet-tudomány egyik módszereként, valamint javasolja, hogy az írott források mellett a történészek is használják a képeket (Basics, 2003. 35. o.). Basics hangsúlyozza, hogy a történészi munkához elengedhetetlen bizonyos adatok feltárása minden képnél, így a pontos cím, leltári szám, őrzési hely, méret, anyag és a technika ismerete fontos (Basics, 2003. 41. o.). Mikonya György szerint a kép sokszor kifejezőbb, mint a szöveg, ám értelmezéséhez holisztikus megközelítés szükséges, így fontos kitérni a készítés körülményeire, az ábrázolás módjára vagy az egyéni jellegzetességekre. A rejtett és szimbolikus tartalom kibontását sokszor utalások segítik (Mikonya, 2011). Basics problémaként felveti, hogy a történelmi eseményekről nem feltétlenül született ábrázolás (Basics, 2003), Kéri Katalin pedig, hogy az elemzett képek sok esetben nem nevelési szituációk ábrázolásának céljával születtek (Kéri, 2001. 99. o.), ugyanakkor a rejtett információkat, melyek esetleg szövegekből, vagy más forrásból nem hozzáférhetőek, segíthetnek feltárni (Géczi, 2008). M. Nádasi Mária dokumentumnak olyan anyagot tekint, mely az adott időponttól számítva maximum egy emberöltőn belül született, és bár nem pedagógiai kutatás céljára készült, de alkalmas arra (M. Nádasi, 2001. 328. o.). Itt már vissza is

\footnotetext{
${ }^{2}$ ikon: 'kép, fatáblára festett bizánci stílusú szentkép', 'stilizált ábra, piktogram', nemzetközi szó a latin icon ('kép') nyomán, amely a görög eikón ('kép, arckép') átvétele (Tótfalusi, 2008). -gráfia: (tudományos szóösszetételek utótagjaként) -rajz, -leírás, gör graphikosz 'az írással vagy rajzzal kapcsolatos' grapho 'ír, rajzol' (Tótfaulsi, 2008).
} 
A gyermekkortörténeti ikonográfia kutatási irányai és lehetőségei

kanyarodhatunk Basics Beatrix gondolatához, mely szerint nem minden eseményről készült hiteles ábrázolás. Ismerni kell az adott korszakot művészettörténeti szempontból, és tudni kell, hogy mely rétegeket szükséges lehántani egy adott kép esetén, és mennyire kell a mélybe hatolnunk, hogy az esetleges neveléstörténeti jelentőséget feltárhassuk. Kéri Katalin kifejti, hogy az ikonográfiát mint módszert alkalmazó neveléstörténésznek a képi forrás kiválasztása tekintetében nagy felelőssége van, hiszen befolyásolja, meghatározhatja a szakmai tudást az adott időszakról (Kéri, 2001). Mindezt szem előtt tartva olyan módszertant szükséges kidolgozni, mely az elemzésre alkalmas képeket kellően szűri, valamint minden egyes kép esetén beágyazható az adott történeti kontextusba, valamint figyelembe veszi M. Nádasi Mária fent említett javaslatát, nevezetesen, hogy egy adott időponttól számítva maximum egy emberöltőn belül született.

\section{A gyermekkortörténeti ikonográfia elhelyezése a magyar képelméleti és neveléstudományi kutatások közt}

Németh András neveléstörténész tanulmányában megfogalmazza azt a jogos elvárást, hogy létesüljenek olyan kereshető adatbázisok, melyek egy-egy korszak neveléstörténetileg releváns képanyagát tárolják (Németh, 2010). Itt szükséges felvetni, hogy az általunk feldolgozott képek és felvonultatott lehetséges elemzési módszerek szükségszerűen nem törekedhetnek a választott korszak gyermekképének teljes ikonográfiai alapú elemzésére, sem a teljes igazság feltárására (Endrődy-Nagy, 2015b). Hazánkban 2008-tól folyamatosan születnek ikonográfiával foglalkozó tanulmányok, illetve olyan munkák, melyek módszertana az ikonográfiára épült; ebben az évben szinte egy időben három kutató jelentetett meg ilyen munkákat, melyek közül kettő jelen Gyermeknevelés lapszámunk szerzője is: Géczi János, Kéri Katalin és Mikonya György (Géczi, 2008; Kéri, 2008; Mikonya, 2008). Ezen munkák előzményeinek tekinthető Péter Katalin 1996-ban publikált Gyermek a kora újkori Magyarországon (Pé- ter, 1996), Baska Gabriella, Nagy Mária és Szabolcs Éva közös munkája (Baska, Nagy és Szabolcs, 2001), valamint Pukánszky Béla A nőnevelés évezredei c. munkája (Pukánszky, 2006), melyek mindegyike elsődleges forrásként képeket is használt. Géczi János Darvai Tiborral közösen publikált tanulmányában jelzi, hogy ezekben a munkákban közös, hogy a gyermekképet bontják ki a történészi felkészültség hátterével (Géczi és Darvai, 2010). 2010-ben szintén megjelent néhány ikonográfiára épülő módszertani tanulmány: Géczi János (Géczi, 2010), illetve Endrödy-Nagy Orsolya tollából (Endrödy-Nagy, 2010), majd a következő lépés két módszertani disszertáció párhuzamos megszületése volt, az egyik Somogyvári Lajosé a fotók elemzésére (Somogyvári, 2015), míg Endrödy-Nagy Orsolya munkája a festészetre fókuszálva mutatott be lehetséges elemzési metódusokat a neveléstörténet számára (Endrödy-Nagy, 2015). Azóta még egy disszertáció született, mely ezzel a módszerrel dolgozik, festményeket elemez, újdonság, hogy egy festőiskola egészére kiterjedő vizsgálatot végez és tárja fel a gyermekképet (Támba, 2016).

A neveléstörténeti kutatásokban a fiatal kutatói generációban jelentős súllyal van jelen az ikonográfiai kutatás, ugyanakkor a levéltári alapokra épülő forráskutatás - például Pirka Veronikának pedagógiai folyóiratok tartalomelemzésére alapozott életreform kutatása (Pirka, 2013) vagy Garai Imre Eötvös Collegiumot bemutató monográfiája (Garai, 2015), vagy Farkas Péter a szabadművelődés irányító szervezeteinek történetét (1945-1949) teljesebbé tevő disszertációja (Farkas, 2016) szintén továbbra is jelentős bázisa a tudományos kutatásnak. A módszertani sokféleség többek közt más tudományterületek bevonásával jöhet létre, így például a diskurzuselemzést Szabó Zoltán András a gráfok bevonásával színesíti kutatói munkájában (Szabó, 2015a; 2015b). Az írott dokumentumok elemzésének természetesen a jövőben is nagy szerepe lesz, azonban a képi, vizuális dokumentumok kutatása árnyalhatja egy-egy korszak neveléstörténetét, gyermekképét. A jövőben fontos együttműködések születhetnek ezen területek kombinációjával. 
A képelméleti kutatások közt az ikonográfiai munkák szintén említésre méltó helyen szerepelnek a Nyíri Kristóf akadémikus vezetésével müködő Képi Tanulás Mühelyében (Nyíri, 2016; Veszelszki, 2017). Elfelejtett képelméletek című munkájában Nyíri Kristóf jelzi, hogy a mühely kutatói mely témaköröket vizsgálják a képtudományon belül: „ikonológia, ikon-téma számítógépkorszak hajnalán, mentális képek, képjelentés-képi hasonlóság-képigazság, képteológia, képprobléma a fogalmi metaforaelméletben, képi metaforák, vizuális retorika, taglejtésnyelv, gyermekrajz, képregény, filmelméletek, az információ vizualizációja" (Nyíri, 2016. 4. o.). Az ikonológiai fejezetnél hivatkozik Mitchellre, aki rámutat, hogy Gombrich és Arnheim kutatásainak köszönhető, hogy a művészettörténet rabságából kikerülve az ikonográfia önálló életre kelve segíti a humántudományok kutatásait (Mitchell, 1980; Nyíri, 2016). A magyar kezdeteknél fontos, hogy említsük az Ikonológia és műértelmezés sorozatot, melyben számos elemzés megjelenhetett. A nemzetközi vonulatnál pedig a PanofskyMitchell-Schapiro kutatók nevével fémjelzett kiindulást tartja indokoltnak. (Nyíri, 2016).

\section{Milyen módszert használhatunk?}

Megismerve számos lehetséges képelemzési módszert, disszertációmban és az erre épülő monográfiámban három - Panofsky 1984ben, Bouteaud 1989-ben, valamint Collier 2001-ben publikált képelemzési módszerét egyesítettem. Az ismertetett módszertan a reneszánsz időszakából 100 különféle képi dokumentum elemzésére adott lehetőséget az ősnyomtatványtól a miniatúrán át a festményekig, felölelve grafikai és festészeti, azaz fekete-fehér és színes alkotásokat. Az egyes bemutatott módszerek akár egy-egy dokumentumtípus bemutatására alkalmasak lehetnek, azonban a kutatás eredményeként kiderült, hogy alapvetően a három módszer kombinációja jelent nagyobb lehetőséget. A jövőben fontos lenne olyan egyszerübb módszer kidolgozása, mely nem feltételez művészettörténeti ismeretet. Olyan módszerre van szükség, mely lehetőséget nyújthat bármilyen kép, legyen az festmény, miniatúra vagy akár fotó elemzésére. Panofsky 1984-ben képelemzési metódusával kapcsolatban (Panofsky, 1984) a módszer hátrányának tartom, hogy alapos művészettörténészi felkészültséget igényel, mellyel nem feltétlenül rendelkezik a képekkel foglalkozó neveléstudományi kutató. A Panofsky-féle módszerre épül Mietzner és Pillarczyk (2005) korábban fóként fotóelemzésekre használt technikája, mely annyiban egészíti ki a Panofsky-féle módszert, hogy mélyebb összefüggésekre enged következtetni a realitás, vagy cél tekintetében. A képelemzésekre főleg technikai háttérismerettel rendelkezőknek ad lehetőséget a francia szakirodalomban feltárt Bouteaud-féle (Bouteaud, 1989) módszer, valamint a vizuális antropológia területére sorolható, sorozatelemzésekre korábban csak fotók esetén kipróbált Collier-féle (Collier, 2001) módszer (Endrödy-Nagy, 2015a; 2015b).

Több módszer kombinációjával alaposabb, árnyaltabb dekódolt információk rajzolódnak ki. A jövő feladata a fent említett tér-idő-nemvilágnézet-nemzeti hovatartozás figyelembevételével kialakítható módszertan, vagy módszertanok kidolgozása. A tanulmány további részében a saját, fent említett módszerem kívánom mintaelemzéssel bemutatni, mely a kutatók körében még kevéssé ismert, valamint egy művészettörténeti elemzésen alapuló a módszertan lépéseit nem részletező elemzéssel.

\section{Három lehetséges módszer egyesített alkalmazása lépésröl lépésre ${ }^{3}$ magyarázattal}

A reneszánsz gyermekképe című munkában részletes és száz képre kiterjedő kvalitatív kutatás keretében mutatom be, hogy lehet három különböző oldalról ugyanazt a képet elemezni. Az ikongráfiai munka az alábbi három módszert mutatja be részletesen (EndrödyNagy, 2015a; 2015b) 4 .

\footnotetext{
${ }^{3}$ A módszertan először a disszertációmban, majd monográfiámban jelent meg (Endrődy-Nagy, 2015a; 2015b)

${ }^{4}$ Jelen keretek közt erre a típusú elemzésre mintaadással nem kívánok kitérni, hiszen ez már megjelent a fent
} 
A gyermekkortörténeti ikonográfia kutatási irányai és lehetőségei

Panofsky (1984) munkája szerint:

1. Preikonografikus leírás, háttérinformációkkal: Itt minden adatot felveszünk, a háttérinformációknak utánanézünk: alkotó, cím, évszám, hol érhető el jelenleg, hol készült, milyen technikával, mekkora méretben stb. Ugyanebben a pontban írjuk le nagyon részletesen, hogy mit látunk a képen.

2. Ikonográfiai jelentések: Javasolt a képleírásban szereplő alakokra párhuzamokat keresni. Jó kiindulás lehet az adott korszak ikonográfiai szimbólumait feltáró lexikonok áttekintése, majd hasonló képek keresése.

3. Ikonológiai szintézis: A feltárt jelentések a korszak művészettörténetébe, történetébe, gyermekkortörténetébe, művelődéstörténetébe ágyazva.

Bouteaud javaslata alapján kitérve a kódokra (Bouteaud 1989):

1. Leírás: Ez megegyezik Panofsky preikonografikus leírásával!

2. Üzenetek: Kereshetünk metaforákat, szimbólumokat a képen, alkotáson.

3. Kódrendszer: Az alábbi részletes leírás segítséget nyújt:

- Technika: hogy készült az alkotás?

- Grafika: ecsetkezelés, grafikai felkészültség megállapítása

- Színtani: mely színeket kombinálja az alkotó, aktív-passzív színek, színkeverés, komplementer színek, színskála, föszínek szerepe

- Tipográfiai: a képeket kísérő szöveg, cím, és a képen látható szövegek betütípusa, elrendezése

- Szín és figurák viszonya: mely figura milyen színeket visel, hord, milyen színű ő maga, milyen színfoltnak érzékeljük?

- Szociokulturális (ruhák, jelzések, esztétika, stílus): mennyire esztétikus az elrendezése a viselt ruháknak és egyéb jelzéseknek a képen, egyáltalán mit viselnek az alakok, milyen egyéb jelzések láthatóak rajtuk. Milyen stílus jelenik meg a képen?

- Nonverbális: A kongruencia kérdése nagyon fontos, illetve maga a nonverbális kommunikáció: gesztusok, mimika, térköz

említett keretek közt, csupán annak magyarázatára mely lépések szükségesek a komplex elemzéshez.
- Társas szituáció: kik vannak a képen, van-e kapcsolatuk egymással, és ha igen, milyen viszony olvasható le a szereplők közt?

Collier munkája alapján (Collier, 2010. 39. o.) sorozatelemzés végezhető, melynek lépései a következők:

1. „Hagyatkozzunk érzéseinkre, nézzük az egész adathalmazt egységként, és rögzítsük az érzéseinket. Hagyjuk, hogy minden benyomás felszínre jöjjön, minden kérdést rögzítsünk, ami motoszkál bennünk, mert lehet, hogy a későbbi analízisnél fontos irányba terel."

2. „Készítsünk leltárt minden képről, a cél függvényében, hogy mit szeretnénk feltárni, készítsünk kategóriarendszert."

3. „Strukturáljuk az elemzést, mérjünk távolságot, számoljunk, hasonlítsunk. $\mathrm{Az}$ evidens kérdéseket is vizsgáljuk meg. Alapos leírásokat készítsünk, és legyenek grafikonok, statisztikai számítógépes elemzések."

4. „Keressük meg a szignifikáns elemeket, úgy, hogy ismét az egészet nézzük, az összes elemet együtt. Ez alapján írjuk le a konklúziót."

Mindhárom módszert kipróbálva a neveléstörténeti magyar nyelvü, illetve a History of Childhood című angol nyelvű szemináriumokon elmondható, hogy az érettségin elsajátítható történelmi ismeretekre támaszkodva Collier módszere kiválóan alkalmazható 5 .

Végső konklúzió: Hogyan vonjuk le a végső konklúziót? Azért szükséges megkülönböztetni a végső konklúziót az egyes módszerekkel feltárt eredményeitől, mert itt a három eredményt szükséges mérlegelni, azonosságokat és különbségeket tenni. A három módszer elvégzése után az adott korszak társadalmi viszonyait, a történeti, művelődéstörténeti hátterét, gyermekkortörténetét ismerve vonható le egy végső konklúzió és árnyalható a gyermekkép.

\footnotetext{
${ }^{5}$ A 2014/2015, 2015/2016, illetve a 2016/2017 tanévekben a tanító-, óvodapedagógus, csecsemő- és kisgyermeknevelő szakos hallgatók közül összessége, minden csoport kipróbálta a fenti módszereket. A szemináriumi módszerek tapasztalatairól egy további tanulmány fog megjelenni.
} 
Endrődy-Nagy Orsolya

\section{Elemzés a müalkotás hátterének múvészettörténeti feltárásával id. Pieter \\ Brueghel: Szamár az iskolában, 1556. címü grafikájának példáján keresztül}

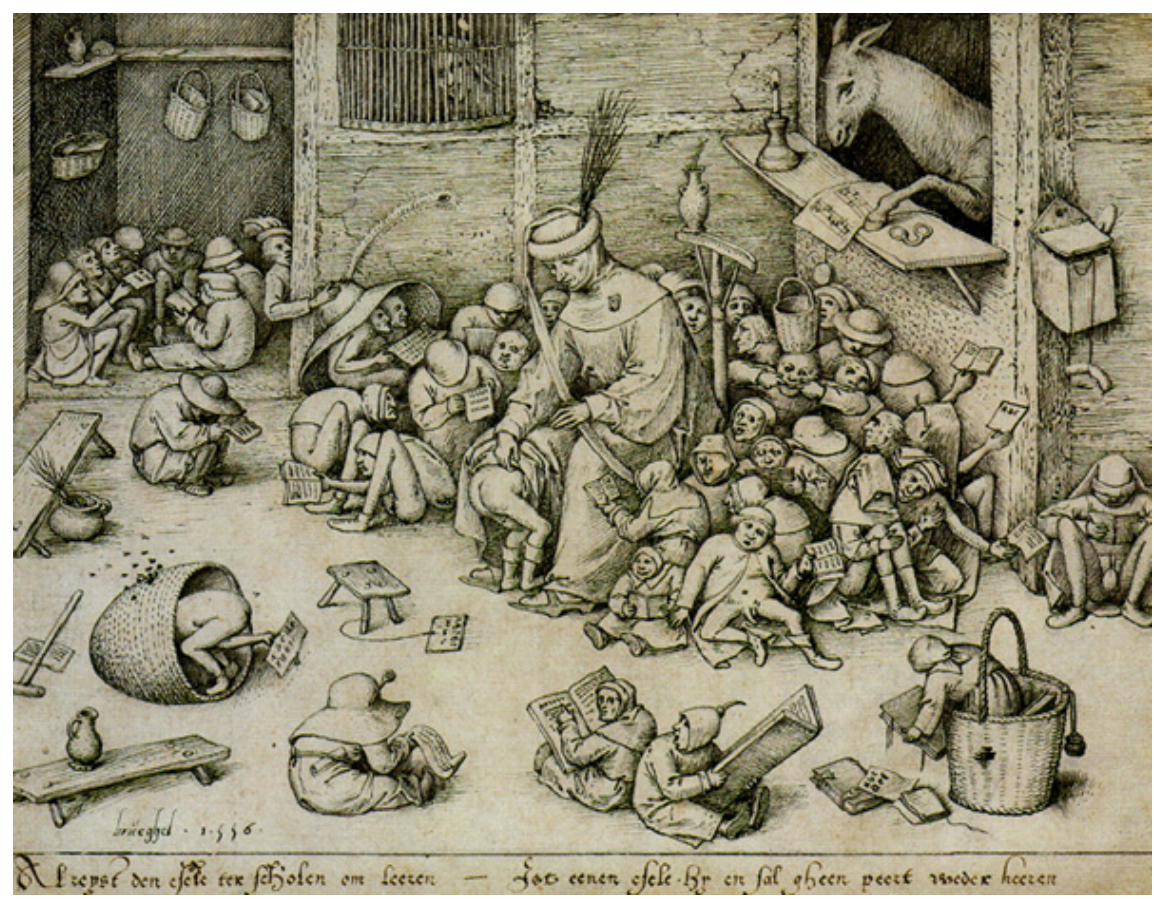

2. ábra: id. Pieter Brueghel: Szamár az iskolában, 1556., toll és tus, Staatliche Museum, Berlin

A humorosnak ható képet 1556-ban alkotta id. Pieter Brueghel. Az iskola és iskoláztatás ilyen típusú ábrázolásmódja azonban nem előzmény nélküli a 16. században, gondoljunk csak Holbein Erasmus ihlette iskolaábrázolására. Erasmus ugyanis azt vallotta, hogy a gyermek ,állati alakot vesz fel, ha nem alkotunk emberi formát belőle" (Erasmus, 1529). Brueghel gondolatai a protestánsok szerint oly sürgető iskolareformok

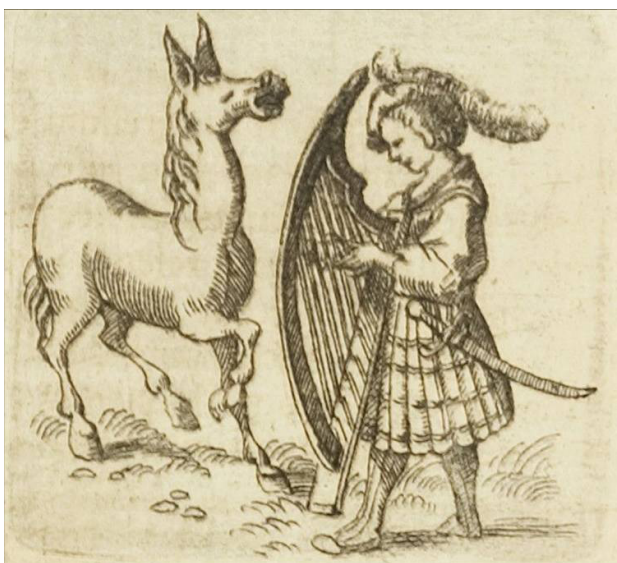

szükségességével is rímelnek. Erasmus Balgaság dicsérete című könyve igen népszerű volt ekkoriban. Ennek lapjait javarészt a balkezes Hans és egy-két esetben a jobbkezes testvére Ambrosius Holbein munkái illusztrálják (Buck, 1999; Müller, 2006). A képek a kötet margóján szerepelnek.

Vessünk csak egy pillantást a képekre: 1 . 3-5. ábra
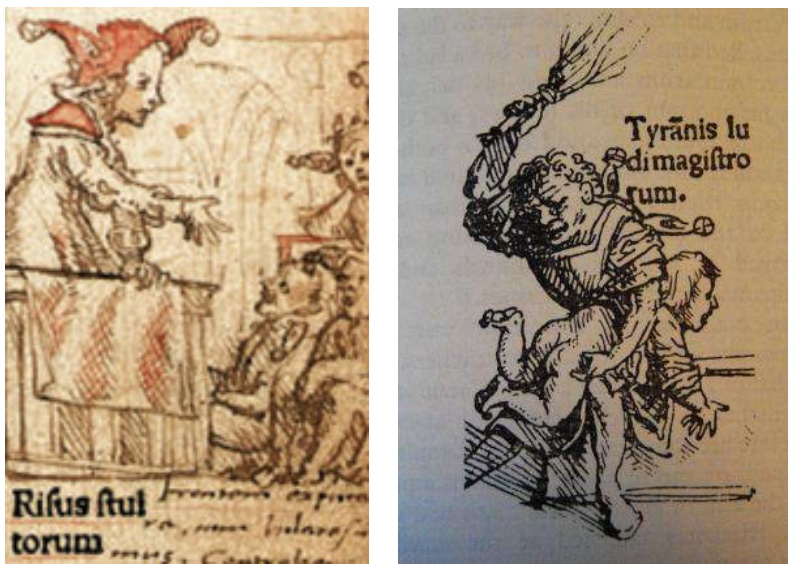

3-5. ábra: Rotterdami Erasmus (1515): A balgaság dicsérete, Ambrosius Holbein, 55. sz. illusztrációja, A szamár és a hárfa, toll és fekete tinta, Bázel, Szépművészeti Múzeum; ifj. Hans Holbein, 1. sz. illusztrációja Bolond a pulpituson, toll és fekete tinta, Bázel, Szépművészeti Múzeum; ifj. Hans Holbein, Az iskolamester tyrannisa, toll és fekete tinta, Bázel, Szépművészeti Múzeum 
A gyermekkortörténeti ikonográfia kutatási irányai és lehetőségei

A 3-5. ábra, valamint a Balgaság dicsérete bizonyára nem volt ismeretlen Brueghel előtt, hisz az illusztrácókból, szinte mozaikként összeállítható a 2. ábrán látott Szamár az iskolában. A vesszőzés motívumának iskolamesterrel való összekapcsolása a korszak több munkáján is látszik, így Albrecht Dürer 6. ábrán közölt fametszetén is. Nézzük csak! Érdemes megfigyelni az iskolamester bibircsókos orrát. Hasonló orrbetegségre utaló Ghirlandaio Nagypapa unokájával című művén láthatunk, ahol egyértelműen megállapítható, hogy Ghirlandaio a természethủ ábrázolás miatt dolgozza ki oly részletgazdagon az orrot. A reneszánsz képzőművészeti gyakran alkalmazzák ezt a trükköt technikai bravúrjuk bemutatásukra, és egyúttal így teszik le névjegyüket (Endrödy-Nagy, 2015a; 2015b). A Dürer-metszet esetén a valósághủ ábrázolást támasztja ezzel alá, azaz valóban létezhetett testi fenyítés. Mindennek nyomait a korszak teoretikusai is alátámasztják.

\section{$213 e r$ rechtbefchevoenivoliveroen Derptrgot trumbyeaufferoen}

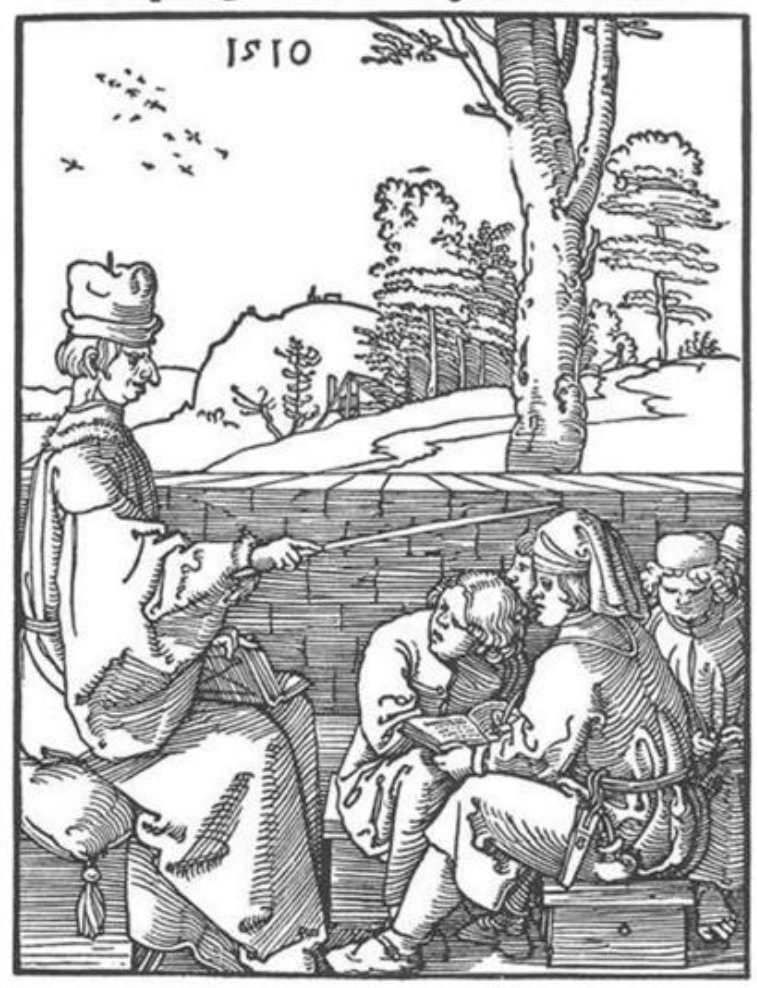

6. ábra: Albrecht Dürer (1510): Iskolamester, fametszet, British Múzeum, London
Ikonográfiai vonatkozások mellett a szépirodalomban sem példanélküli a szamár vagy szamárfej osztálytermi környezetbe való helyezése. Egy 1479-es fametszeten, mely a Rodericus Zamorensis-féle Spiegel des Menschlichen Lebens illusztrációja, az osztályteremben valaki szamárfejet visel (Bagley, 1984). Az iskolába járó szamár motívuma az irodalomban is többször felmerült, már 1180-ban is, először Nigellus Wireker szerzetes szatirikus költeményében, a Speculum Stultorumban (Balgák tüköre) (Világirodalmi kislexikon, II. 1976). A korban kedvelt tanítómesék, példázatok egy jellegzetes darabja ez, állatmesébe öltöztetett szerzeteseket ostorozó szatíra, ridicula. A szatírában Wireker főként az egyházat és a szerzeteseket kritizálta, de egy részben az egész emberiség és az iskola ellen is kikel. A Balgák tükörének föszereplője Brunellus, a szamár. Brunellus túl rövidnek találja a farkát, ezért megszökik gazdájától, és Salernóba megy, hogy egyetemista legyen, és így megtalálhassa a farkának meghosszabbítására való szereket, eszközöket. Itt azonban mégsem iratkozik be a híres orvosi egyetemre. Egy londoni kereskedő rásózza csodaszeres fioláit, de azok sem segítenek. Beiratkozik a párizsi egyetemre is, hátha tudós lesz. Az angol diákokkal hét éven át dorbézol, mert azt hiszi, így ő is angol úriember lesz. Mindezek után is azonban csak „iá”-t tud mondani, így hazaindul, s szerzetes szeretne lenni. Egyik renddel sincs megelégedve, ezért azt gondolja, hogy majd ő alapít egyet, ám gazdája rátalál. Hiába a sok kalandozás, ismét teherhordó állat lesz.

A mulattatás középkori eszköze volt tehát az idézett ridicula. Ugyancsak gyakori volt az élő szóban előadott farce, ami tulajdonképp a komédia előfutára. Farce-okat vásárokon és egyéb ünnepi alkalmakkor láthatott a középkori közönség. Brueghel ismerhette a jellegzetes Zenész szamár címü farce-ot is (Szigeti, 2009). Nem tudhatjuk, Erasmus ismerte-e a fent említett műveket, de az biztos, hogy mindkettő évszázadokig igen nagy népszerüségnek örvendett. A Speculum Stultorum jó néhány példányát őrzik szerte Európa legnagyobb könyvtáraiban Dublintól Prágán át 
Kölnig (Bagley, 1984). Az is bizonyos, hogy mind Erasmus, mint Brueghel iskolaképében találunk hasonlóságokat, rokon vonásokat.

A kép komplex szimbólum, hisz kifejezheti egyszerre, hogy a diákok szamarak, vagy, mivel igen kiemelt helyet foglal el a képen (mintegy katedrára emelve), hogy a tanár a szamár. Érdekes játék a szavakkal a kép angol címe: „Ass at the school” - az ass ugyanis a fenék szleng változata, és a kép középpontjában épp egy csupaszfenekü gyereket („szamarat”?) látunk, akit a tanár épp elfenekel. (A szatirikus hangvételü kép egyébként a mai napig Brueghel egyik legkelendőbb, legtöbbször reprodukált alkotása.) A csupasz fenekű gyerekről párhuzam juthat eszünkbe. Brueghel a Saul megtérése című opuszában Sault háttal ábrázolja egy anatómiailag szinte hibátlanul festett ló hátsóján ülve. Korábbi kutatásaimban beazonosítottam, hogy, Saul nem más, mint Alba herceg. Mindkét esetben a fenék a kritikát fejezi ki, de míg Alba herceg "portréja” esetén annyit tesz: „nem fogom megfesteni az arcodat", a Szamár az iskolában esetén az üzenet komoly iskolakritikát jelent. Erre utalhat konkrétan a szamár mint állati alak megjelenése a metszeten.

Ez az iskolaábrázolás számos kérdést vet fel, a korszak oktatással kapcsolatos nézeteiről. Bár a tanár középen helyezkedik el, szemmel láthatóan vetélytársra akadt a szamárral, tekintélye azonos az állatéval. Körülötte vihogó, huncutkodó, oda nem figyelő diákok tömege. Különösen érdemes felfigyelni arra, hogy legalább 30 gyerek van a tanító háta mögött. A szamár a diákok háta mögött helyezkedik el (talán egy közülük), de istállójából figyeli a terem eseményeit, akár egy iskolamester. Ráadásul kottát olvas, szemüvege lazán az iromány mellé téve. Az egész képen egyedül ő az, aki iskolára jellemző elmélyült tevékenységet folytat; feltűnően intelligensnek hat a sok gyerek közt. Néhány körülötte ülő gyermek arca olyan, mintha nagyon idős illetve beteg lenne. Talán kivételt képez a rendetlenkedők közül az a hatfös csoport, akik a sarokban szinte megbújva figyelmesen olvasgatják könyvüket. (Ez kifejezheti azt is, hogy mennyire háttérbe szorul maga a tanulás az iskolában.) Brueghel nagy valószínűséggel saját tapasztalatai alapján festett korképet a korabeli iskoláról, hisz feljegyzések bizonyítják, hogy előszeretettel bújt meg észrevétlenül hétköznapi és ünnepi eseményeken. Erre utalhat az a kép hátsó részében elhelyezkedő figura is, aki egy rácsos megfigyelő ablak mögött leskelődik.

A tanár-iskolamester ábrázolása igen nevetséges, tollas kalapja, semmibe révedő tekintete alapján akár felfedezhetjük a Brueghel más képein szívesen ábrázolt bolond figuráját is. Persze ezzel azt is kifejezheti, hogy mi a véleménye arról, aki tanít. Zumthor kutatásaira támaszkodva jelzi, hogy ekkoriban sok olyan iskolamester akadt, aki még az ábécé betűit sem tudta megnevezni (Zumthor, 1985). Mindez a gondolat sokban rokon Erasmus feljegyzéseivel, aki a tanítókról így vall: „A gyermeket alig négyesztendős korában iskolába küldik, ahol egy tudatlan, durva, romlott erkölcsü, néha nem is józan eszü, gyakran holdkóros vagy nyavalyatörős vagy úgynevezett francia betegségben szenvedő tanító trónol. [...] Gondold el, mennyi sok termékeny elmét tesznek tönkre ama tudatlan, de a tudás hitében fölfuvalkodott, mogorva, részeges, durva hóhérok, kik kedvtelésből vernek; kiknek oly vad a lelkületük, hogy más ember kínzásában gyönyörüségüket lelik. Az effajta embereknek mészárosoknak vagy hóhéroknak kellene lenniük, s nem gyermekek alakítóinak." (Erasmus, 1529, idézi Kéri, 1999).

Monika Poniatowska tanulmányában a szamár-szimbólum jelentőségét vizsgálja a vallásban és a kultúrában. Tanulmányában kitér arra, hogy a Jézust szíve alatt hordó Szűz Máriát, illetve a Jeruzsálembe bevonuló Jézust hordó szamarat összeköti valami, mégpedig az, hogy egyedül ő nem látta Jézust, de mindenki más igen, így - átvitt értelemben - a szamár a megújulás, haladás és egyúttal a pogányság szimbóluma: bár nem látja az új tanokat hirdető Jézust, mégis elöreviszi (Poniatowska, 2009). Ha ezt a gondolatot a képen alkalmazzuk, akkor ismét a reformáció szimbólumaként értelmezhetjük az alkotást. Hiába áll a középpontban a tanítómester középkori szemlélete és állatias brutalitása, a háttérben már ott áll a reformá- 
A gyermekkortörténeti ikonográfia kutatási irányai és lehetőségei

ció jelképeként a szamár; ő ugyan nem látja a fejlődést, de jelenléte biztosítja, hogy már az általa szimbolizált gondolatok jelen vannak a németalföldi gondolkodásban, valójában a tanítómester az állatias, „szamár”, és a szamár az élet tanítómestere, a haladó (hiába van bevagy kizárva). Megemlítendő még a szamárral kapcsolatban a szamárünnep jelensége, ami a középkorban egyet jelentett a bolondozással és a fordított nappal. Ezen a napon mindennek a fordítottja számított normálisnak (Németh, 2008). Visszautalva a már elemzett tanító-szamár kettősségre és felcserélhetőségre: a képen a tanítóról valószínúleg Brughelnek az a véleménye, hogy ő a szamár és a szamár a tanító.

A szamár mint szimbólum kifejezheti azt is, hogy bolondság olyanokat próbálni tanítani, akik egyáltalán nem az osztályterembe valók, hisz a szamár nem képes megtanulni semmit.Azaz, ha szimbólumként értjük, és általánosságban a balgákról beszél, akkor azt mondja, hogy a balga hiába tanul. Ám ha ez volt a festő véleménye, akkor a reformáció erőfeszítéseiről is igen lesújtó képe lehetett. Vajon azt gondolta, hogy hiába minden iskolareformra vonatkozó erőfeszítés?

Bár Brueghel fóként paraszti életképek festésével foglalatoskodott, ez a metszet egyik legismertebb alkotása. Összességében kibontható, hogy a kor iskolarendszerének kritikájaként és a reformok szükségességének sürgetőjeként értelmezhető elsősorban a műalkotás.

\section{A gyermekkortörténeti ikonográfia hasznossága, eredményei lehetséges alkalmazási lehetőségei}

Az elmúlt évtizedben az ikonográfiai módszer új utakat nyitott a történeti- és neveléstörténeti kutatásokban, tágítva a kutatók megismerési lehetőségeit. A gyermekkortörténeti kutatásokban elsősorban az adott korszakban szöveges dokumentumokból kibontható gyermekképi narratívákat árnyalhatja.

Számos tanulmány (Péter, 1998; Pukánszky, 2001; Géczi, 2008, 2010; Mikonya, 2008; Kéri, 2010; Endrödy-Nagy, 2010; 2013; Támba, 2014; Földesi, 2017; Janek és Balogh, 2017; Somogy- vári, 2017), valamint szakdolgozat (Mucsiné, 2017) született az elmúlt évtizedben, mely az ikonográfiai módszertant használja. Az elmúlt két évben pedig az átfogó munkák, melyek egy-egy terület, illetve korszak gyermekképét színesítik (Somogyvári, 2015; Endrődy-Nagy, 2015; Támba, 2016). A kutatók összefogásával, további módszertani munkákkal, közös szimpóziumok és publikációk létrehozásával a területfontos altudományterületté válhat, elősegítve ezáltal a gyermeknevelési, iskoláztatási szokások alaposabb megismerését, és különösen a gyermekek iránti attitűd feltárását.

A közeljövő feladata, hogy megszülessen egy olyan átfogó munka, mely a gyermekkortörténeti ikonográfia lehetséges módszertanát tárgyalja. Ez a munka előfeltétele, hogy egy-egy korszakról ikonográfiai munkák szülessenek, az adott korszak képeken kirajzolódó gyermekképi narratíváinak kibontásával.

Az ikonográfia, tágabb értelemben a vizuális kutatások melybe beletartoznak a plasztikai elemzések (Pataky, 2017), rajzelemzések (Hortoványi, 2017) is nagy kihívások előtt áll. Szükségesnek és egyúttal megtermékenyítőnek látszik a különböző tudományterületekkel összekapcsolni a gyermekkortörténeti, gyermektudományi kutatásokat, mint amelyre példa a most induló bronzkori régészetet és gyermekkortörténetet összekapcsoló kutatás (Fülöp, 2017), annak megállapítására, vajon hány éves gyermek lehetett képes az egyes tárgyi dokumentumok előállítására. Az ikonográfia módszerét és tágabb értelemben a vizuális kutatásokat kiválóan lehet használni a nyelvészeti, így például az etnopszicholingvisztikai kutatásokban is, mint a Lacuna-elmélet, mely szerint bizonyos szókészlet egy adott kultúrára jellemző (Markovina és Lénárt, 2016), ha kisgyermekeket vizsgálunk a két módszertan egyesítésével. A koragyermekkor kutatásának is új irányokat, eredményeket adhat, ha több tudományterületet sikerül bevonni a gyermekkorkutatásába.

Fontos lenne a gyökerekhez visszanyúlni és fontos lehet a hasonló területeken kutató művészettörténészekkel - mint például Virág Ágnes (Virág, 2017) - és képtudománnyal 
foglalkozó vizuális kutatókkal a már működő Képi Tanulás Műhelye a jövőben is kutatócsoportban együttmüködni (Nyíri, 2016; Veszelszki, 2017). A feladat az, hogy egymás eredményeit felhasználva egyre mélyebben feltájuk a vizuális kutatásokban rejlő lehetőségeket, megmutassuk a távolabbi területek kutatóinak, hogy a képolvasás lehetséges, sőt kimondottan hasznos, hisz Thomka szavaival élve először betűzgetjük a képeket, aztán megtanuljuk olvasni.

\section{Felhasznált irodalom}

Asmann, Jan (2013): A kulturális emlékezet, Atlantis könyvkiadó, Budapest.

Bal, Mieke (1998): Látvány és narratíva egyensúlya, In: Thomka Beáta (szerk.): Narratívák 1., Képleírás, képi elbeszélés, Kijárat kiadó, Budapest, 155-181.

Basics Beatrix (2003): Történeti ikonográfia, In: Bertényi Iván (szerk.): A történelem segédtudományai, Osiris, Budapest, 40-50.

Baska Gabriella, Nagy Mária és Szabolcs Éva (2001): Magyar tanító, 1901, Iskolakultúrakönyvek 9., Iskolakultúra, Pécs.

Bagley, A. (1984): Brueghel's The Ass at school, Pedagogica Historica, 24. 2. sz., 357-378.

Boutaud, J.-J. (1989): Application des recherches en iconographie publicitaire á la pédagogie de l'expression en I.U.T, ANRT, Lille 3, France.

Buck, S. (1999): Hans Holbein, Könemann, Cologne.

Collier, M. (2010): Approches to analísis in visual antropology, In. van Leeuwen, T. \& Jewitt, C. (eds.): Handbook of Visual Analysis, Sage, Los Angeles-London-New Delhi-SingaporeWashington, 35-61.

Donald, M. (2001): Az emberi gondolkodás eredete, Osiris, Budapest.

Endrődy-Nagy Orsolya (2010): Gyermekkép a 16. századi Németalföldön id. Peter Brueghel művein. Iskolakultúra, 20. 7-8. sz., 137-147.

Endrődy-Nagy Orsolya (2013): Középkori gyermekkép-narratívák? In: Benedek András et al. (szerk): Új kutatások a neveléstudományban 2012 - A munka és a nevelés világa a tudományban, MTA-PTB, ELTE Eötvös kiadó, Budapest, 267-288.

URL: http://mek.oszk.hu/12100/12188/

Endrődy-Nagy Orsolya (2015a): A reneszánsz gyermekképe - a gyermekkép reneszánsza 1455-
1517 között Európában - ikonográfiai elemzés, doktori disszertáció, Eötvös Loránd Tudományegyetem, Pedagógiai és Pszichológiai Kar, Neveléstudományi Doktori Iskola, Budapest.

Endrődy-Nagy Orsolya (2015b): A reneszánsz gyermekképe - a gyermekkép reneszánsza 1455-1517 között Európában - ikonográfiai elemzés, doktori disszertáció, Eötvös Kiadó, Takács Etel Pedagógiai Alapítvány, Budapest.

Erasmus, Rotterdami (1529): A verésről, In: dr. Kéri Katalin (1999, szerk.): Tovatünő álom, Válogatás a gyermekkortörténet európai forrásaiból, Fegyelmezés, gyermekbántalmazás c. fejezet, Pécs.

URL: http://mek.oszk.hu/02100/02102

Farkas Péter (2016): A koalíciós időszak iskolarendszeren kívüli felnöttképzés-politikája. Adalékok a szabadmüvelödés irányitó szervezeteinek történetéhez (1945-1949), Doktori disszertáció, kézirat, ELTE, Budapest

Fülöp Kristóf (2017): Különleges késő bronzkori gyermeksír és miniatür edénykészlete. Tisicum. A Jász-Nagykun-Szolnok Megyei Múzeumok Évkönyve XXV.

Gadamer, Hans-Georg (1994): Épületek és képek olvasása. In: Hans-Georg Gadamer A szép aktualitása. T-Twin. Budapest. 157-169.

Gadamer, Hans-Georg (2004): Igazság és módszer, Osiris, Budapest.

Garai Imre (2015): A tanári elitképzés műhelye: A Báró Eötvös József Collegium története 18951950, ELTE Eötvös József Collegium, Budapest.

Géczi János (2008): Ikonológia-ikonográfia mint a történeti pedagógia segédtudománya. Iskolakultúra, 18. 1-2. szám, 108-119.

Géczi János (2010): A szocialista nevelésügy két képi hangsúlya. Iskolakultúra, 20. 1. szám, 79-91.

Hagen, R.-M. \& Hagen, R. (2004): Pieter Brueghel, the Elder, Peasants, Fools and Demons. Tashen, Köln.

Hortoványi Judit (2017): Szimbólumok rajzai, rajzok szimbólumai - Szimbólumrajzok pedagógiai használatának lehetőségei kamaszkorban, Gyermeknevelés, 5. 1. sz., 155-170.

Huizinga, Johann (1979): A középkor alkonya, Európa Kiadó, Budapest.

Janek Noémi és Balog Beáta (2017): Képekben elbeszélt múlt - Mesterházy Jenő, Gyermeknevelés, 5. 1. sz., 85-109.

Kéri Katalin (2001): Bevezetés a neveléstörténeti kutatások módszereibe, Müszaki Kiadó, Budapest. 
A gyermekkortörténeti ikonográfia kutatási irányai és lehetőségei

Kéri Katalin (2008): Gyermekábrázolás az 1950-es években a Nők Lapja címoldalain, In: Kozma Tamás - Perjés István (szerk.): Új kutatások a neveléstudományokban, MTA Pedagógiai Bizottság, Budapest, 203-212.

Kéri Katalin (2017): Tanult lányok, emancipált nők ábrázolása dualizmus kori karikatúrákon, Ikonográfiai kutatások a neveléstörténetben Pécsen, Gyermeknevelés, 5. 1. sz., 4-16.

Kress, G. \& Leeuwen, T. van (2006): Reading Images, The Grammar of Visual Design, Routledge, Taylor \& Francis Group London and New York.

Kulcsár-Szabó Zoltán (2005): Hermeneutikai szakadékok, Csokonai kiadó, Debrecen.

Kurcz Ágnes (1976): Középkori latin irodalom In: Köpeczi Béla és Pók Lajos (szerk.): Világirodalmi Kisenciklopédia II. kötet, Gondolat, Budapest, 672-674.

Markovina, I. Y. \& Lénárt, I. (2016): CrossCultural Investigation of the Concept of Business: a New Step in the Development of the Lacuna Theory, Journal of Psycholinguistics, 3. 29. sz., 145-162.

Mietzner, U. \& Pilarczyk, U. (2005): Methods of Image Analysis in Research in Educational and Social Sciences, In: Mietzner, U., Myers, K. and Peim, N. (eds.): Visual History, Images of Education, Peter Lang AG, European Academic Publishers, Bern, 109-129.

Mészáros István, Németh András és Pukánszky Béla (2003, szerk.): Neveléstörténet szöveggyüjtemény. Osiris, Budapest, 62-64.

Mikonya György (2008): Gyermekkor az 1950-es években - a dokumentarista fotográfia alapján. In: Perjés István és Ollé János (szerk.): Hatékony tudomány, pedagógiai kultúra, sikeres iskola: VIII. Országos Neveléstudományi Konferencia: Program és összefoglalók.

Mikonya György (2011): Életútelemzés és az ikonográfia alkalmazása a nevelés történetében In: Tölgyesi József (szerk.): A modern pedagógia új dimenziói: Konferencia Bábosik István professzor 70. születésnapja tiszteletére. Kodolányi János Főiskola, Székesfehérvár, 79-89.

Mikonya György (2017): Ikonográfia és életképek a 20. század eleji Magyarországról, Gyermeknevelés, 5. 1. sz., 64-84.

M. Nádasi Mária (2004): Dokumentumelemzés In: Falus Iván: Bevezetés a pedagógiai kutatások módszereibe, Müszaki kiadó, Budapest, 317-330.
Mucsiné Isaszegi Irina (2017): Középkori gyermekgondozási szokások és eszközök korabeli képzőművészeti alkotások tükrében, Gyermeknevelés, 5. 1. sz., 43-54.

Müller, Ch., Kemperdick. S., Ainsworth, M. (2006): Hans Holbein the Younger: The Basel Years, 1515-1532, Prestel, Munich.

Németh András (2010): A pedagógiatörténet funkcióváltozása és annak megjelenése a hazai kutatásokban, In: Szabolcs Éva (szerk.): Neveléstudomány - reflexió - innováció, Gondolat kiadó, Budapest, 149-188.

Németh István (2008): Az élet csalfa tükrei: Holland életképfestészet Rembrandt korában. Typotex, Budapest.

Nyíri Kristóf (2009): Gombrich on Image and Time, Journal of Art Historiography, 1. 1. sz., 1-13.

Nyíri Kristóf (2016): Elfelejtett képelméletek, In: Benedek András és Nyíri Kristóf (szerk.): Képi Tanulás Mühelye Füzetek, 2016/3. Budapest, 3-56.

Panofsky, Erwin (1984): A jelentés a vizuális müvészetekben, Gondolat Kiadó, Budapest.

Pataky Gabriella (2017): Plasztikai képességek fejlődése 3-7 éves korban a CEFR_VL kompetenciamodell tükrében. Diagnosztikus vizsgálat a síkbeli (2D) és a térbeli (3D) alkotások köréből a vizuális nevelés rendszerében, Gyermeknevelés, 5. 1. sz., 171-187.

Péter Katalin (1996): Gyermek a kora újkori Magyarországon, Magyar Tudományos Akadémia Történettudományi Intézete, Budapest

Poniatowska, Monika (2009): A szamár mint szimbólum a vallásban és a kultúrában, COMMUNIO, 1-2. sz., 38-44.

Pirka Veronika (2013): Az életreform-mozgalmak hatása a pedagógiai nyilvánosság alakulására az 1920-as, ,30-as években Magyarországon. Doktori Disszertáció, ELTE PPK, Budapest.

Pukánszky Béla (2006): A nőnevelés évezredei, Gondolat, Budapest

Schapiro, M. (1983): Words and pictures, Mouton, Hague-Paris.

Somogyvári Lajos (2015): Ikonográfia a neveléstörténet-irásban. Pedagógiai életképek a hatvanas évekböl, Gondolat, Budapest.

Somogyvári Lajos (2017): Lenin, a gyermek -Politikai ikonográfia és pedagógia az államszocializmusban, Gyermeknevelés, 5. 1. sz., $55-63$. 
Szabó Zoltán András (2015a): Hálózat - tudomány - történet. Szakirodalmi áttekintés és módszertani javaslatok a magyar neveléstudomány 1945 és 1989 közötti kommunikációs sajátosságainak feltárásához. In: Németh András, Biró Zsuzsanna Hanna és Garai Imre (szerk.): Neveléstudomány és tudományos elit a 20. század második felében. Gondolat Kiadó, Budapest, 83-111.

URL:https://edit.elte.hu/xmlui/handle/10831/ 32131

Szabó Zoltán András (2015a): Hivatkozási mintázatok, izoláció és ülésvezetői kontroll az 1924. évi középiskolai törvény nemzetgyűlési vitájában. Iskolakultúra, 25. 4. sz., 78-91.

URL: http://epa.oszk.hu/00000/00011/00194/ pdf/EPA00011_iskolakultura_2015_04_ 078-091.pdf

Szigeti Csaba (2009): IV. Exkurzus: A mulatságos és a komoly a középkori irodalomban, In: Szigeti Csaba: Szöveggyüjtemény a középkori retorikák és poétikák szeminárium számára, Miskolci Egyetem, Miskolc, 27-41.

Szőnyi György Endre és Szauter Dóra (2008): A képek politikája, Mitchell, W.J.T. válogatott írásai, JATE Press, Szeged.

Támba Renátó (2014): Fiúgyermek-ábrázolás az alföldi festészetben, Valóság, 57. 7. sz., 10-35.
Támba Renátó (2016): Gyermekkor és gyermeknevelés a vásznakon, A dualizmuskori gyermekszemlélet megjelenitése egy festöiskola példáján, disszertáció, Debreceni Egyetem, Bölcsészettudományi Kar, Debrecen.

Támba Renátó (2017): A gyermek a természetben. A fürdés és a víz motívuma a 19. század második felének, illetve a Szolnoki Művésztelep néhány alkotójának gyermekábrázolásain. Gyermeknevelés, 5. 1. sz., 17-42.

Thomka Beáta (1998): Képi időszerkezetek, In: Thomka Beáta (szerk.): Narratívák 1., Képleirás, képi elbeszélés, Kijárat kiadó, Budapest, 7-17.

Tótfalusi István (2008): IDEGENSZÓ-TÁR, Idegen szavak értelmező és etimológiai szótára, Tinta Könyvkiadó, Budapest.

Veszelszki Ágnes (2017): Visual Learning Lab Képi Tanulás Műhelye, Gyermeknevelés, 5. 1. sz., 188-190.

Virág Ágnes (2017): A kortárs képelemzés kognitív szempontú megközelítése, Gyermeknevelés, 5. 1. sz., 123-142.

Zumthor, P. (1985): Hollandia hétköznapjai Rembrandt korában, Gondolat, Budapest.

\section{Iconography in History of Childhood: Possibilities of Research Methods and Topics}

The topic of this paper are the possibilities in the Iconographic research made in the field of History of Education, particulary in History of Childhood. The paper presents an overview of the researches published in Hungary since 2008 and provides an example of a research method for the visual analysis itself. The aim of the essay is to explain, how do we read images, and suggest research perspectives of the visual research method; which is focusing on the possible research outcomes working with images and texts at the same time.

Keywords: iconography, History of Childhood, methods of visual analysis, reading images, hermeneutics

Endrődy-Nagy Orsolya (2017): A gyermekkortörténeti ikonográfia kutatási irányai és lehetőségei. Gyermeknevelés, 5. 1. sz., X-X. 